\title{
Differential Trafficking of AMPA and NMDA Receptors during Long-Term Potentiation in Awake Adult Animals
}

\author{
Joanna M. Williams, ${ }^{1}$ Diane Guévremont, ${ }^{1}$ Sara E. Mason-Parker, ${ }^{2}$ Carthika Luxmanan, ${ }^{1}$ Warren P. Tate, ${ }^{3}$ and \\ Wickliffe C. Abraham ${ }^{2}$ \\ ${ }^{1}$ Departments of Anatomy and Structural Biology, ${ }^{2}$ Psychology, and ${ }^{3}$ Biochemistry, University of Otago, Dunedin, New Zealand
}

\begin{abstract}
Despite a wealth of evidence in vitro that AMPA receptors are inserted into the postsynaptic membrane during long-term potentiation (LTP), it remains unclear whether this occurs in vivo at physiological concentrations of receptors. To address the issue of whether native AMPA or NMDA receptors undergo such trafficking during LTP in the adult brain, we examined the synaptic and surface expression of glutamate receptor subunits during the early induction phase of LTP in the dentate gyrus of awake adult rats. Induction of LTP was accompanied by a rapid NMDA receptor-dependent increase in surface expression of glutamate receptor 1-3 (GluR1-3) subunits. However, in the postsynaptic density fraction only GluR1 accumulated. GluR2/3-containing AMPA receptors, in contrast, were targeted exclusively to extrasynaptic sites in a protein synthesis-dependent manner. NMDA receptor subunits exhibited a delayed accumulation, both at the membrane surface and in postsynaptic densities, that was dependent on protein synthesis. These data suggest that trafficking of native GluR1-containing AMPA receptors to synapses is important for early-phase LTP in awake adult animals, and that this increase is followed homeostatically by a protein synthesis-dependent trafficking of NMDA receptors.
\end{abstract}

Key words: glutamate receptor; long-term potentiation; dentate gyrus; awake animal; synaptoneurosome; postsynaptic density; trafficking

\section{Introduction}

There is strong evidence that the expression of long-term potentiation (LTP) is governed in part by modulation of postsynaptic ionotropic glutamate receptors (Lee et al., 2000; Malinow and Malenka, 2002), especially through regulated trafficking of specific AMPARs to the cell surface (Shi et al., 1999; Hayashi et al., 2000). Current understanding based on in vitro models is that naive synapses contain a constitutive, rapidly cycling synaptic AMPAR component comprising glutamate receptor $2 / 3$ (GluR2/3) subunits. However, during LTP, there is a protein kinase $\mathrm{A}$ and $\alpha$-calcium/calmodulin-dependent protein kinase IIdependent exocytosis of GluR1-containing receptors to extrasynaptic membranes (Passafaro et al., 2001) followed by movement of the receptors to synapses (Chen et al., 2000). The very early phase of LTP appears to involve insertion of homomeric GluR1 receptors, which are replaced later by GluR2-containing receptors via the constitutive pathway (McCormack et al., 2006; Plant et al., 2006), although this has been challenged recently (Adesnik and Nicoll, 2007).

Constitutive insertion of NMDARs into synapses occurs at a slower rate than AMPAR cycling (Huh and Wenthold, 1999; Ehlers, 2000), but as for AMPARs it can be bidirectionally changed in parallel with induced plasticity (Barria and Malinow, 2002; Grosshans et al., 2002; Nong et al., 2003; Watt et

Received Sept. 6, 2006; revised Sept. 26, 2007; accepted 0ct. 30, 2007.

This work was supported by grants from the New Zealand Health Research Council, the Neurological Foundation of New Zealand, National Institutes of Health Grant NSO21184, and the University of Otago.

Correspondence should be addressed to Dr. Joanna M. Williams, Department of Anatomy and Structural Biology, University of 0tago, Box 913, Dunedin, New Zealand. E-mail: joanna.williams@stonebow.otago.ac.nz. D0I:10.1523/JNEUROSCI.2348-07.2007

Copyright $\odot 2007$ Society for Neuroscience $\quad 0270-6474 / 07 / 2714171-08 \$ 15.00 / 0$ al., 2004). The functional role of NMDAR trafficking may be to control metaplastically the ability of synapses to undergo further plasticity (Montgomery et al., 2005; Perez-Otano and Ehlers, 2005).

Because most studies of glutamate receptor trafficking have been performed using immature cultures or acute slices, it is not yet known whether the mechanisms identified from these studies can be directly extrapolated to adult tissue in vivo. Whereas fear conditioning in rats is associated with trafficking of overexpressed GluR1 to synapses in amygdalar neurons, as measured electrophysiologically (Rumpel et al., 2005), LTP induction in young adult hippocampal slices is not associated with AMPAR but with NMDAR trafficking to the cell surface, as measured biochemically (Grosshans et al., 2002). This latter result contrasts with a previous ultrastructural study which showed that medial perforant path LTP induced in anesthetized animals resulted in an increase in synaptic AMPARs, but not NMDARs (Moga et al., 2006). Other studies have observed increases in glutamate receptor subunits in global synaptic fractions from various preparations, but without localizing the increased receptor complement within the synaptic compartment (Nayak et al., 1998; Williams et al., 1998, 2003; Heynen et al., 2000; Zhong et al., 2006). Thus, it remains uncertain whether trafficking of native AMPARs to synapses contributes to LTP in physiological situations. Given the importance of understanding the mechanisms of LTP in freely moving adult animals, we investigated whether early-phase LTP induced in the dentate gyrus of awake adult rats changes the cell-surface expression of native glutamate receptors. We found that LTP was indeed associated with a rapid increase in native AMPAR expression at the cell surface, with a specific increase in the number of GluR1-containing receptors in the postsynaptic 
density. Synaptic NMDAR expression also increased, but in a delayed and protein synthesis-dependent manner.

\section{Materials and Methods}

All experiments were conducted on the perforant path-dentate gyrus synapses in adult male Sprague Dawley rats (400-550 g, 4-6 months old at the time of surgery), using surgical protocols approved by the University of Otago Animal Ethics Committee and in accord with New Zealand animal welfare legislation, as previously reported (Williams et al., 2003). Electrophysiology. Beginning 2 weeks postsurgery, animals were taken to a recording room and tested for usable field potential recordings evoked by perforant path stimulation (fEPSP slope $\geq 3.5 \mathrm{mV} / \mathrm{ms}$ at stimulus currents $\leq 500 \mu \mathrm{A}$ ). If the recordings met these criteria, baseline testing $(0.05-0.017 \mathrm{~Hz}, 150 \mu$ s pulse duration, alternating between the two hemispheres for $20 \mathrm{~min}$ ) was undertaken, using a stimulus strength that elicited a $2-4 \mathrm{mV}$ population spike. Baseline recordings were made at the same time of day (during the animal's light cycle) two to three times per week until a stable level of evoked responses was obtained for at least four consecutive sessions (i.e., the responses varied by less than $\pm 5 \%$ ). On the day of LTP induction, high-frequency stimulation (HFS) was delivered after a $10 \mathrm{~min}$ baseline recording period, and responses were followed for another $20 \mathrm{~min}$. LTP was calculated relative to the average fEPSP recorded over the 5 min before tetanus.

Conditioning protocols. LTP at perforant path synapses was induced by 50 trains of $400 \mathrm{~Hz}$ stimulation ( $250 \mu$ s pulse duration, 10 pulses/train, in sets of 5 trains $1 \mathrm{~s}$ apart, with $60 \mathrm{~s}$ between sets) to the angular bundle. This procedure reliably produces a persistent increase in the fEPSP for at least several weeks (Williams et al., 2003). In some experiments, the standard 50 trains of HFS were given in the presence of either the competitive NMDA receptor antagonist, 3-3(2-carboxypiperazin-4-yl) propyl-1-phosphate (CPP; 10-20 $\mathrm{mg} / \mathrm{kg}$, i.p., 2 h before HFS; Tocris, Bristol, UK), or the protein synthesis inhibitor cycloheximide $(5 \mathrm{mg} / \mathrm{kg}$, i.p., 1 h before HFS, Sigma, St. Louis, $\mathrm{MO})$. Low-frequency stimulation, when given, consisted of the same number of stimulus pulses as the HFS (500), but the pulses were given at $1 \mathrm{~Hz}$ in trains of 10 pulses, with $10 \mathrm{~s}$ between trains. All animals were tetanized unilaterally so that the unstimulated hemisphere could serve as a withinanimal control. For Western blot analysis, animals were anesthetized with halothane and decapitated at various times post-tetanization. The dentate gyrus was dissected from the rest of the hippocampus and either frozen in liquid nitrogen before protein extraction or used immediately to prepare synaptoneurosomes.

Preparation of cellular and synaptic fractions. All cellular and synaptic protein extracts were prepared from individual control and tetanized dentate gyri. Whole cell extracts were prepared by sonication in a CHAPS (3-[(3-cholamidopropyl)dimethyl-ammonio]-1-propanesulfonate; Roche Diagnostics, Mannheim, Germany)-based homogenization buffer (Williams et al., 1998). Synaptoneurosomes were prepared essentially according to the method of Hollingsworth et al. (1985) as described previously (Williams et al., 2003). Cell-surface proteins and PSDassociated proteins were prepared separately from fixed amounts (200 $\mu \mathrm{g})$ of synaptoneurosomes. Cell-surface proteins were isolated by reversible tagging with a membrane-impermeable biotin moiety $(1.5 \mathrm{mg} / \mathrm{ml}$ sulfo-NHS-SS-biotin; 21331; $30 \mathrm{~min}, 4^{\circ} \mathrm{C}$; Pierce, Rockford, IL) (Chen et al., 1999; Salvatore et al., 2003). Unreacted biotin was quenched by addition of $100 \mathrm{~mm}$ glycine and removed by extensive washing. Membranes were disrupted by sonication in solubilization buffer ( 1 mM EGTA, $1 \mathrm{~mm}$ EDTA, 1 mM PMSF, Complete protease inhibitor; Roche, Welwyn Garden City, UK; 1\% Triton X-100; Bio-Rad, Hercules, CA) in PBS. Biotinbound proteins were precipitated by addition of Neutravidin conjugated to agarose beads $\left(29200 ; 2 \mathrm{~h}, 4^{\circ} \mathrm{C}\right.$; Pierce). Cell-surface proteins were released from the biotin-neutravidin complex by incubation in $50 \mathrm{~mm}$ Tris-Cl, $1 \%$ SDS, and $100 \mathrm{~mm} \mathrm{DTT}\left(10 \mathrm{~min}, 95^{\circ} \mathrm{C}\right)$. After precipitation of the agarose beads, the supernatants were aliquoted and stored at $-20^{\circ} \mathrm{C}$ before Western blot analysis. Postsynaptic density-enriched fractions were prepared from synaptoneurosomes by homogenization in HEPES buffer containing 1\% Triton X-100 (Strack et al., 1997) and incubation on ice for $15 \mathrm{~min}$. PSD-enriched material was precipitated by centrifugation $(16,000 \times g / 20 \mathrm{~min})$, solubilized in PSD-extraction buffer containing $1 \%$ SDS and stored at $-20^{\circ} \mathrm{C}$ before Western blot analysis.
Quantitative Western blot analysis. For analysis of whole-cell extracts and synaptoneurosomes, a fixed amount of protein $(25 \mu \mathrm{g})$ was subjected to Western blot analysis, whereas for analysis of cell-surface proteins or the PSD-enriched fractions, a fixed proportion of protein derived from a standard amount of synaptoneurosomes $(200 \mu \mathrm{g})$ was used. Protein extracts were separated by SDS-PAGE (9\%) and transferred to nitrocellulose membrane (Schleicher and Schuell, Keene, NH). Membranes were probed either with an antibody recognizing GluR1 (Upstate, Lake Placid, NY; 05-855), GluR2 (Zymed, San Francisco, CA; 32-0300), GluR3 (Zymed; 32-0400), NR1 (Zymed; 32-0500) NR2A (Zymed; $32-$ 0600), NR2B (Zymed; 71-8600), PSD-95 (BD Biosciences, Franklin Lakes, NJ; P-45320), GABA ${ }_{\mathrm{B}} \mathrm{R}$ (Chemicon, Temecula, CA; AB5848), $\alpha$-tubulin (Abcam, Cambridge, UK; ab4074) or calnexin (H70) (Santa Cruz Biotechnologies, Santa Cruz, CA; s.c.-11397). Antibodies were detected using appropriate HRP-conjugated secondary antibodies and either Chemiluminescent reagent (GE Healthcare Bio-Sciences, Piscataway, NJ) or Supersignal West Pico (Pierce). X-ray films were scanned using a Bio-Rad imaging densitometer and quantified using Molecular Analyst software. All densitometric analysis was performed within the linear range of the film and detection system. In addition, the experimenter analyzed the results while blind to the hemisphere that received HFS. All data were derived from within-animal comparisons (i.e., data for the tetanized hemisphere were expressed relative to the values determined for the matched contralateral control hemisphere). Because each animal provided a limited amount of tissue protein, not all antibodies could be used with proteins from the same tissue sample; thus, leading to variations in the number of animals used for each antibody. Average densitometric data are reported as mean \pm SEM. To determine whether there was a significant difference between tetanized and control hemispheres within a group of animals, the data were subjected to two-tailed paired $t$ tests. In all instances, a probability level of $\leq 0.05$ was accepted as statistically significant.

Quantitative PCR. Total RNA was isolated using the Trizol reagent (Invitrogen, Carlsbad, CA), from individual control and stimulated dentate gyri 20 min post-LTP induction, or from left and right dentate gyri from unstimulated animals. cDNA was synthesized from total RNA (1 $\mu \mathrm{g})$ using SuperscriptIII (200U; Invitrogen) and random hexamers (250 ng). Quantitative PCR was performed using $5 \mu \mathrm{l}$ of a 1:50 dilution of the cDNA, ABsolute QPCR SYBR Green ROX mix (ABgene, Epsom, UK), and $70 \mathrm{~nm}$ gene specific primers (Proligo Primers and Probes; Sigma) (for details, see supplemental Table 1, available at www.jneurosci.org as supplemental material). Assays were performed using an Applied Biosystems (Foster City, CA) Prism 7000 Sequence Detection System (1 cycle UNG activation at $50^{\circ} \mathrm{C}$ for $2 \mathrm{~min}, 1$ cycle enzyme activation at $95^{\circ} \mathrm{C}$ for $15 \mathrm{~min}$ and 40 cycles of denaturation at $95^{\circ} \mathrm{C}$ for $15 \mathrm{~s}$ and annealing/ extension at $60^{\circ} \mathrm{C}$ for $1 \mathrm{~min}$ ). Threshold cycle (Ct) values for $z i f / 268$ and $n r 2 b$ were normalized to $18 \mathrm{~S}$ rRNA. The comparative Ct method was used for quantification of the transcript expression levels. Significance was analyzed using Student's unpaired t tests. Dissociation curves were analyzed, and amplicons were evaluated by gel electrophoresis to confirm a single PCR product of predicted size.

\section{Results}

\section{AMPAR cell-surface expression rapidly increases after LTP induction in awake rats}

To determine whether trafficking of AMPAR occurs in vivo in response to stimulation paradigms known to produce persistent LTP, it was first necessary to develop an appropriate protocol to monitor surface expression of membrane-associated proteins. Analysis of surface expressed proteins is routinely performed in isolated cells in culture (Chen et al., 1999; Skeberdis et al., 2001; Scheurer et al., 2005) and protocols have been developed previously for membrane-enriched preparations (Taubenblatt et al., 1999; Salvatore et al., 2003) and acute hippocampal slices (Holman and Henley, 2007). In our studies, we first isolated synaptoneurosomes (Hollingsworth et al., 1985; Williams et al., 2003; Mockett et al., 2007), a biochemical preparation known to be enriched with synaptic proteins, as confirmed in the present 
study (supplemental Fig. 1, available at www.jneurosci.org as supplemental material). We then recovered putative surface membrane-associated proteins from this fraction by biotinylation and subsequent precipitation with a Neutravidin-agarose conjugate. This was followed by Western blot analysis to assess which proteins were present within the putative surface membrane fraction. In control experiments, this methodology yielded a quantitative recovery of glutamate receptor subunits from the recovered membrane fractions (Fig. $1 A, B$ ). We then showed that this fraction is specifically enriched for cell-surface proteins as internal proteins such as calnexin, an endoplasmic reticulum integral membrane protein, and $\alpha$-tubulin, a microtubuleassociated protein, were not detected (Fig. $1 B$ ). All proteins in contrast were detected in the original synaptoneurosome homogenate (Fig. $1 B$ ), a finding also consistent with previously published data (Liao et al., 2007). These results indicate that biotinylation and precipitation from synaptoneurosomes produces a fraction that is highly enriched for cell surface membrane proteins. Accordingly, we used this protocol to investigate whether the complement of glutamate receptors found within this fraction was altered when LTP was induced in vivo.

HFS of perforant path synapses in the dentate gyrus of freely moving rats using our standard $400 \mathrm{~Hz}$ protocol produced $36 \pm$ $4 \%$ potentiation of field EPSPs (fEPSPs) measured 20 min postHFS $(n=16)$ (Fig. $2 A$ ). In other animals given exactly the same protocol, potentiation was routinely observed to last for at least 2 weeks ( $40 \pm 5 \%, n=8$ ) (Williams et al., 2003). To assess glutamate receptor cell surface expression we isolated synaptoneurosomes from dissected dentate gyri at various times post-HFS, and cell-surface proteins were recovered as described above. Using this approach and Western blot analysis comparing matched tetanized and control dentate gyri, we found that LTP induced an immediate (nominally 0 min post-HFS) increase in cell-surface GluR1 ( $68 \pm 22 \%, n=14, p=0.003)$, as well as an unexpectedly robust increase in GluR3 ( $95 \pm 26 \%, n=9, p=0.002)$ expression, but no significant change in GluR2 levels ( $12 \pm 9 \%, n=6)$ (Fig. $2 \mathrm{~B}, \mathrm{C}$ ). By $20 \mathrm{~min}$ post-HFS, GluR2 AMPAR subunits were significantly elevated, along with GluR1 and 3 (GluR1, $67 \pm 21 \%$, $n=7, p=0.02$; GluR2, $102 \pm 29 \%, n=4, p=0.04$; GluR3, $96 \pm$ $26 \%, n=7, p=0.01$ ).

To determine whether the late-phase of LTP was also associated with an increased surface expression of AMPAR subunits, tissue was collected at $4 \mathrm{~h}$ post-HFS. Unlike for the early timepoints, only GluR2 showed a significant elevation in cell-surface expression $(37 \pm 15 \%, n=9, p=0.04)$ (Fig. $2 C$ ).

\section{AMPAR subunit levels after LTP induction}

In principle, the increased surface expression of AMPAR subunits could have resulted from an overall increase in the number of available receptor subunits (Nayak et al., 1998; Heynen et al., 2000). However, when AMPAR subunit levels were measured in synaptoneurosomes, there was no change in GluR1-3 expression at any time-point post-HFS, apart from a small increase in synaptoneurosomal GluR1 at $20 \mathrm{~min}$ post-HFS $(17 \pm 7 \%, n=11$, $p=0.04$ ) (Fig. 2D) and a small decrease in GluR3 levels at $4 \mathrm{~h}$ post-HFS $(-15 \pm 3 \%, n=4, p=0.004)$. Additionally, Western blot analysis of whole-cell extracts revealed no increase in expression of any GluR subunits at either 20 min or $4 \mathrm{~h}$ after HFS (Fig. $2 E)$, although there was a modest decrease in GluR3 levels at $4 \mathrm{~h}$ $(-19 \pm 6, n=4, p=0.04)$. This latter result is consistent with the GluR3 decrease observed in synaptoneurosomes and is therefore suggestive of either reduced GluR3 synthesis or enhanced degradation at this time-point. Overall, the fact that we found at best only small and delayed changes in the total and synaptoneurosomal levels of GluR subunits points strongly to the conclusion that their rapid accumulation at the surface membrane reflects a redistribution of the existing supply of AMPARs toward the synaptic and perisynaptic membrane.

\section{NMDAR trafficking follows AMPAR cell-surface expression}

In previous studies, we observed a significant increase in the levels of NR2A and NR2B subunits in whole cell extracts (Williams et al., 1998) and a significant increase in NR2B levels in synaptoneurosomal extracts 20 min post-HFS (Williams et al., 2003). No change in NR1 levels was detected in either preparation at this time-point. Here, we have extended these studies to measure the relative amounts of NMDAR subunits in control and LTPstimulated cell-surface extracts (Fig. 3). Although there was no significant immediate $(0 \mathrm{~min})$ change in the cell-surface expression of NR1, NR2A or NR2B, significant increases did occur by $20 \mathrm{~min}$ post-HFS (NR1, $59 \pm 21 \%, n=6, p=0.03$; NR2B, $83 \pm 29 \%, n=$ $9, p=0.02)$, with a trend toward an increase for NR2A ( $41 \pm 25 \%$, $n=5$; not significant). At $4 \mathrm{~h}$ post-HFS, a significant increase remained for NR2B cell-surface expression $(26 \pm 6 \%, n=4, p=0.02)$ but not for NR1 $(-2 \pm 21 \%, n=5)$ or NR2A $(2 \pm 20 \%, n=4)$. These data show that, relative to the immediate trafficking of AMPARs to the cell surface during LTP, the surface accumulation of NMDARs was delayed. As for AMPAR subunits, the increased NMDAR subunit surface expression decayed over time.

\section{Relation between LTP induction and increased AMPAR and NMDAR surface expression}

Is the change in cell-surface expression of glutamate receptors related to LTP induction or to neural activity per se? We addressed this question using two different strategies. First, low-frequency stimulation at $1 \mathrm{~Hz}$, using the same number of stimulus pulses as given during HFS, neither induced LTP or LTD $(-0.3 \pm 3 \% 20 \mathrm{~min}$ post-HFS; $n=5)$, nor altered cell-surface expression of GluR1 ( $2 \pm$ $19 \%, n=4)$ or NR1 $(3 \pm 12 \%, n=5)$ (data not shown). Second the NMDAR antagonist CPP, used at a dose $(10-20 \mathrm{mg} / \mathrm{kg})$ reported previously to block LTP (Abraham and Mason, 1988), blocked both the induction of LTP $(0.5 \pm 2 \%, n=8)$ (Fig. $4 A)$ as well as the increase in cell-surface expression of the various glutamate receptor subunits (Fig. $4 B, C$ ). Unexpectedly, HFS in the presence of CPP led to a significant reduction in the cell-surface expression of GluR3 $(-41 \pm 4 \%, n=5, p<0.001)$ (Fig. $4 B$ ), indicative of an activitydependent internalization of GluR3-containing AMPARs that is revealed by NMDAR blockade.

\section{Protein synthesis dependence of glutamate receptor cell-surface expression}

Because LTP induction increased cell surface expression of synaptoneurosomal GluR1 and NR2B, it is conceivable that synaptodendritic protein synthesis may play a role in the AMPA or NMDAR trafficking. However, because AMPAR trafficking occurred so rapidly, and NMDAR trafficking was more delayed, we hypothesized that only NMDAR trafficking is dependent on new protein synthesis. To test this hypothesis, LTP was induced in animals given the protein synthesis inhibitor cycloheximide ( 5 $\mathrm{mg} / \mathrm{kg}$, i.p.) $1 \mathrm{~h}$ before HFS. Cycloheximide did not significantly affect the degree of early LTP measured 20 min post-HFS ( $28 \pm$ $4 \%, n=11$ ) (Fig. $4 A$ ), and did not affect the associated trafficking of GluR1-containing receptors to the cell surface $(67 \pm 12 \%, n=$ $4, p=0.01$ ) (Fig. 4B). However, the cell-surface expression of the other glutamate receptor subunits was reduced or prevented by cycloheximide, and was no longer significantly different from the 
a

\section{GluR1}

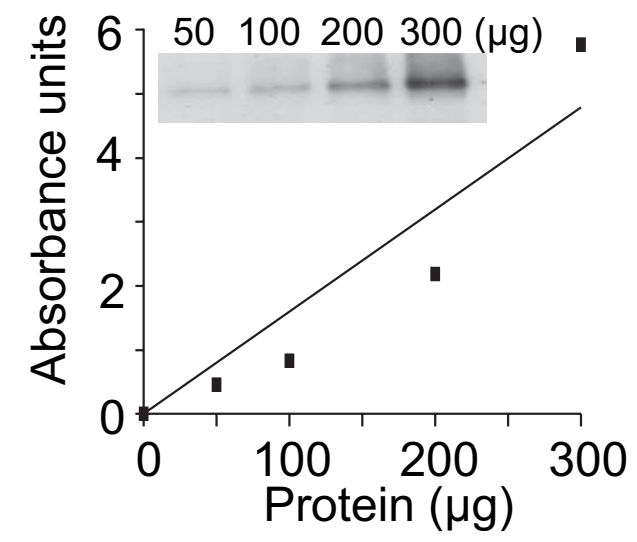

b

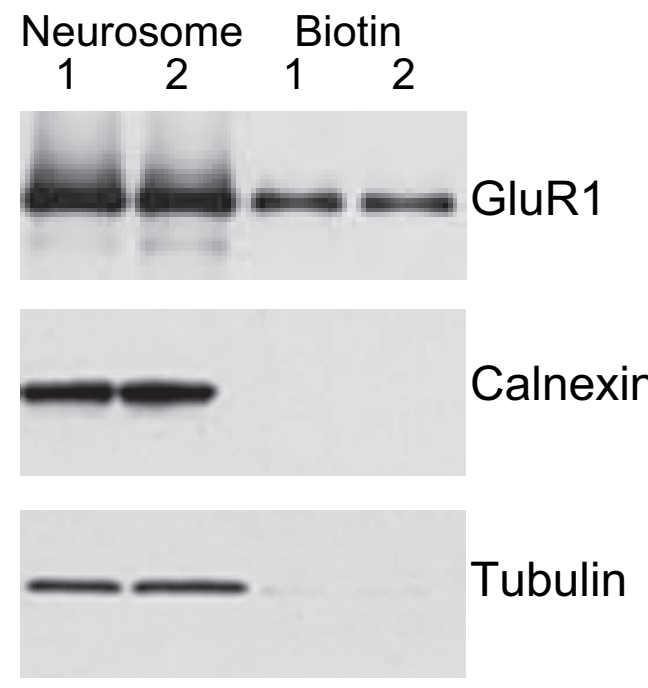

C

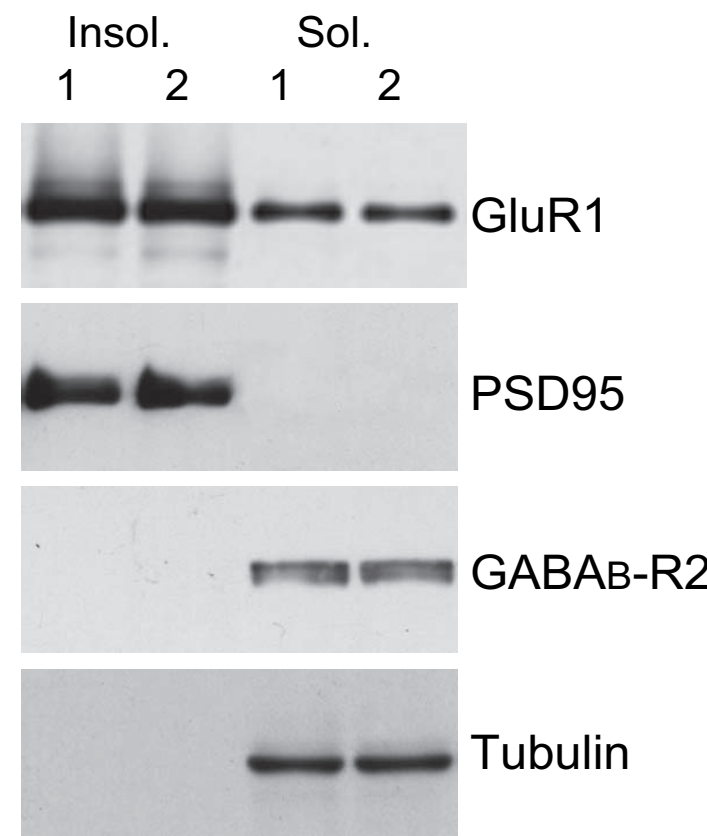

Figure 1. Characterization of membrane subfractions prepared from dentate gyrus synaptoneurosomes. $\boldsymbol{a}, \boldsymbol{b}$, Western blot and densitometric quantitation showing that biotinneutravidin precipitation could recover a proportional amount of GluR1 ( $106 \mathrm{kDa})$ subunits from increasing amounts $(50-300 \mu \mathrm{g})$ of synaptoneurosomal protein $(\boldsymbol{a})$ and equivalent amounts of GluR1 subunit ( $\boldsymbol{b}$, top) were recovered from each of paired matched hemispheres (1:Left and control hemisphere (Fig. 4B,C). Cycloheximide also prevented the increase in synaptoneurosomal levels of GluR1, reported above, and the increase in synaptoneurosomal NR2B previously reported in Williams et al. (2003). Thus, the cycloheximidetreated animals showed GluR1 levels at only $7 \pm 7 \%(n=4)$ and NR2B levels at $1 \pm 13 \%(n=7)$ above baseline (data not shown).

The block by cycloheximide of both the increase in synaptoneurosomal NR2B and the increase in cell-surface expression of NR1 and NR2B supports our hypothesis that the de novo synthesis of NR2 subunits is required for assembly with pre-existing NR1 and trafficking to the cell membrane (Williams et al. 2003). To further address this question, we used quantitative PCR to determine whether $n r 2 b$ mRNA levels were increased $20 \mathrm{~min}$ post-HFS, the same time point at which protein levels are increased in both synaptoneurosomes and whole homogenates (Williams et al., 1998; Williams et al., 2003). The expression of zif/268, an inducible transcription factor associated with LTP persistence, was used as a positive control. As predicted, no significant increase in $n r 2 b$ mRNA was detected $(1.35 \pm 0.23$-fold change, $n=13, p=0.159$ ), although $z i f / 268$ increased by 11 -fold (Fig. 5). Given these results, and the rapidity of the cell-surface expression, we consider it likely that the trafficking of NMDARs is dependent on local synaptodendritic synthesis of NR2B from pre-existing mRNA.

\section{LTP induction is associated with increased levels of GluR1 and NR1 in postsynaptic densities}

The biotinylation method of tagging surface receptors is not able to distinguish between synaptic and extrasynaptic localization. Therefore, we used a more direct measure of synaptic subunit expression by isolating a PSD-enriched fraction from the synaptoneurosomes. In control experiments, this fraction was shown to be enriched for the PSD marker protein PSD95, but conversely did not contain detectable levels of the membrane-bound extrasynaptic $\mathrm{GABA}_{\mathrm{B}}$ receptor or the intracellular protein, $\alpha$-tubulin (Fig. 1C). We found that LTP induced an immediate (nominally 0 min post-HFS) increase in GluR1 levels (50 $\pm 17 \%, n=6, p=0.05)$. In contrast, there was no significant change in any other AMPAR or NMDAR subunit tested at this time point (Fig. $6 A, B$ ). Additionally, we found that HFS elicited a specific increase in the levels of GluR1 $(32 \pm 11 \%, n=8, p=$ 0.03 ) and NR1 ( $45 \pm 18 \%, n=8, p=0.04$ ) in the PSD fraction 20 min post-HFS, but no detectable change in either GluR2 or GluR3. Increases of $\sim 20 \%$ were found for NR2A and NR2B (Fig. $6 A, B$ ), and although they did not reach statistical significance, these changes fit well with the $45 \%$ increase in NR1, assuming that the newly inserted NMDARs contained equal amounts of NR2A and NR2B in tetrameric complexes. Given the smaller percentage increase for GluR1 in the PSDs compared with the total cell surface (compare with Fig. 2C), it appears that GluR1 is trafficked to both synaptic and extrasynaptic membranes. Furthermore, the lack of change in

2:Right) when equivalent amounts (200 $\mu \mathrm{g})$ of synaptoneurosomal protein were used in the biotin-neutravidin precipitation. "Neurosome" is $20 \mu \mathrm{g}$ of synaptoneurosomal protein (without precipitation), and "biotin" is $20 \%$ of the total yield of protein eluted from the biotinneutravidin beads. $\boldsymbol{b}$, Bottom, № calnexin $(90 \mathrm{kDa})$ or tubulin $(50 \mathrm{kDa})$ were recovered in the biotin-neutravidin precipitated fractions, but were readily detected in the synaptoneurosome fractions. $C$, Western blot analysis demonstrating that the Triton- $X$ insoluble fraction (Insol.) recovered from synaptoneurosomes contained GluR1 subunits and the postsynaptic density marker protein, PSD95, but not the extrasynaptic receptor $\mathrm{GABA}_{B} \mathrm{R}(105 \mathrm{kDa})$ or tubulin. The Triton- $X$ soluble fraction (Sol.) in contrast contained just detectable levels of GluR1 as well as readily detectable amounts of $\mathrm{GABA}_{B} R$ and tubulin. 
a

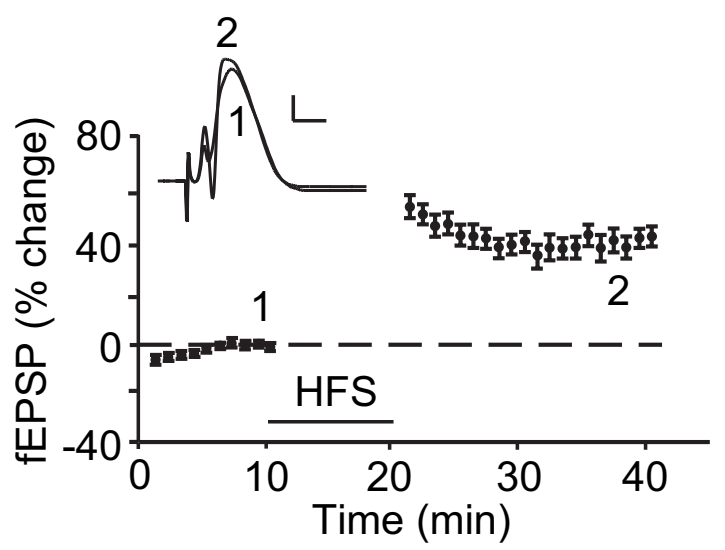

b

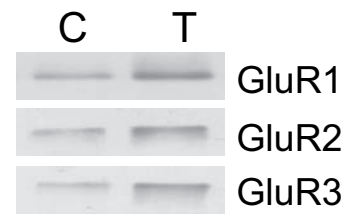

C
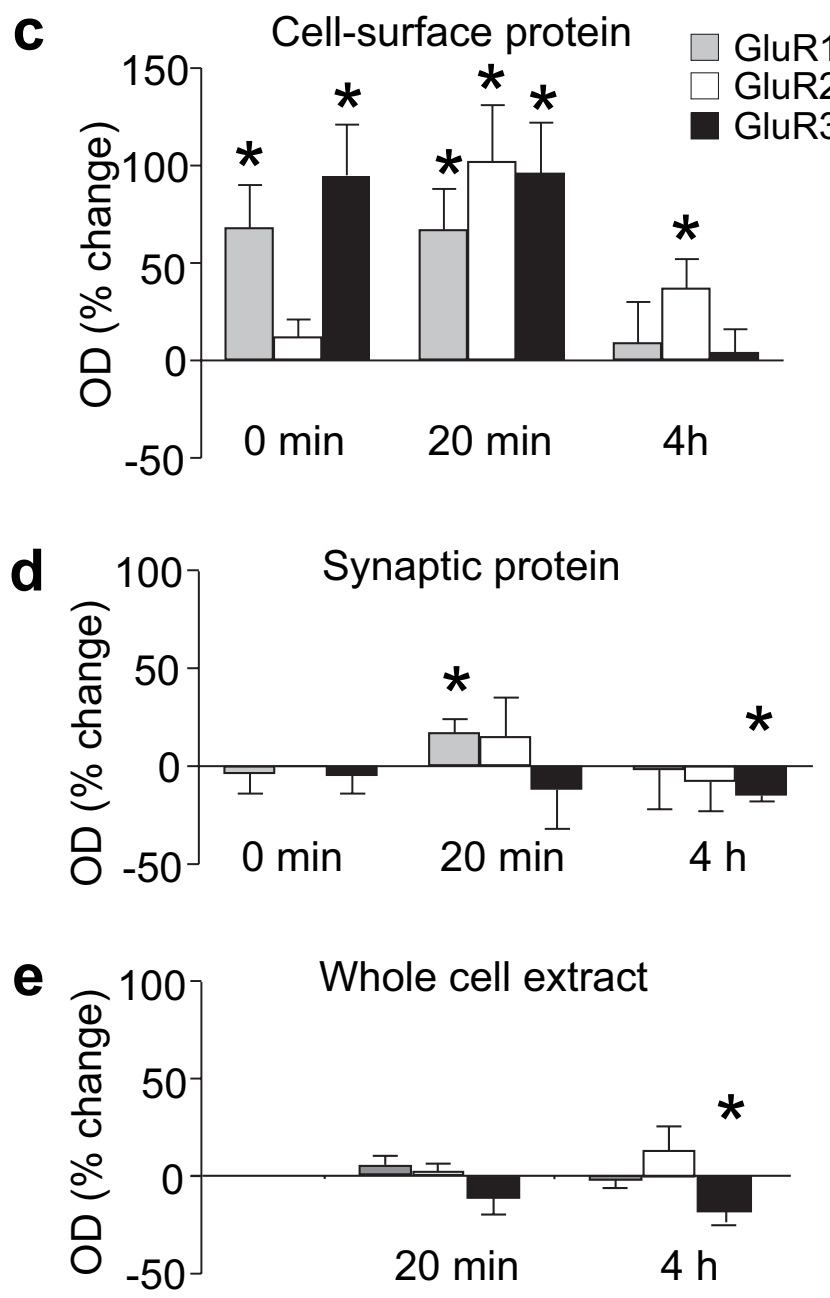

Figure 2. AMPARsubunit expression after the induction of LTP in the dentate gyrus of awake rats. $\boldsymbol{a}$, Induction of LTP by HFS in a group of 16 rats used for Western blot analyses at the $20 \mathrm{~min}$ time-point. Data are mean \pm SEM fEPSP slopes are expressed as a percentage of the baseline recordings made 5 min before HFS (bar). Waveforms are averages of 20 sweeps taken at the times indicated for a single animal. Calibration: $5 \mathrm{mV}, 5 \mathrm{~ms}$. Western blot analysis was used to assess the relative levels of AMPAR subunits in cell-surface and synaptic extracts. $\boldsymbol{b}$, Sample Western blots showing GluR1-3 levels in cell-surface extracts isolated 20 min post-HFS from

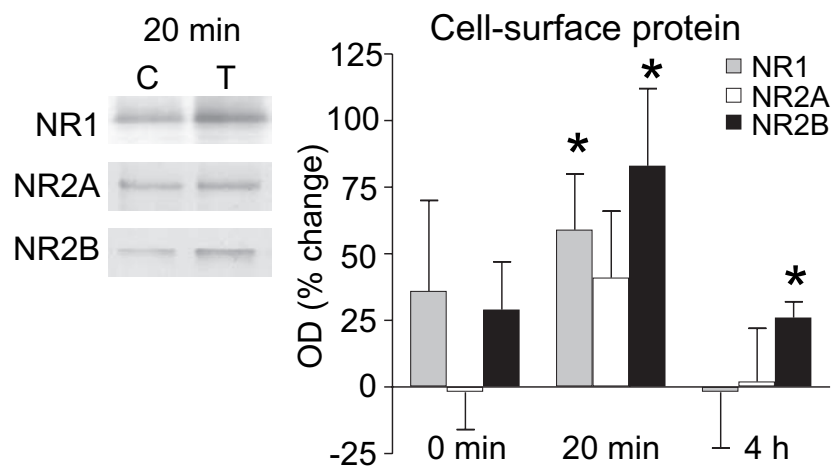

Figure 3. NMDAR subunit expression at the cell-surface of synaptoneurosomes after LTP in awake rats. There was a significant increase in NR1 and NR2B at 20 min and a trend toward an increase in NR2A levels, but no significant changes at 0 min post-HFS, relative to the control hemisphere $(n=4-9)$. By $4 \mathrm{~h}$ post-HFS, only NR2B remained elevated. Sample Western blots comparing control and tetanized hemispheres, as per Figure 2, are shown for the NMDAR subunits, 20 min post-HFS.

GluR2/3 in the PSDs supports our interpretation that the GluR2/3 cell-surface change is fully extrasynaptic at this time-point.

\section{Discussion}

The present findings indicate that dentate gyrus synapses upregulate expression of both AMPAR and NMDAR native receptors at the cell surface in a rapid and sequential manner during the early phase of LTP in adult awake rats. Soon after HFS, there is a general increase in the number of GluR1-3 subunits presented to the cell surface, although in the PSD the increase is selective to GluR1-containing receptors. The rise in AMPAR cell-surface expression is accompanied by a delayed increase in the cell-surface expression of NMDARs. We interpret these findings as reflecting changes in the expression of functional AMPARs and NMDARs, because evidence points to the full assembly of receptors before their trafficking to the cell membrane (Malinow and Malenka, 2002; Wenthold et al., 2003). These in vivo findings build on the extensive body of knowledge regarding glutamate receptor trafficking derived from in vitro studies, where assessments of turnover rates suggest that the very rapid receptor accumulation observed in the present study is likely caused by active externalization of receptors rather than blocked endocytosis of cycling cell-surface receptors (Lissin et al., 1998). Thus, we propose that the early phase of LTP in the dentate gyrus of awake rats is expressed at least in part by exocytosis and insertion of GluR1containing AMPARs at postsynaptic sites.

\section{Relation between LTP and synaptic levels of} GluR1-containing AMPARs

The cell-surface expression of AMPAR subunits correlated extremely well with the induction of early-phase LTP in the dentate

$\leftarrow$

matched control $(\mathrm{C})$ and tetanized $(\mathrm{T})$ hemispheres from a single animal. $\boldsymbol{c}$, Histogram of average optical densities (ODs) showing a rapid increase in cell-surface expression of GluR1-3 subunits at various times post-HFS ( $n=6-14)$. d, Histogram of average 0Ds showing GluR1-3 subunit levels in synaptoneurosomes at various times post-HFS. GluR subunits did not increase in synaptoneurosomes 0 or 20 min post-HFS ( $n$ values $=4-8$ ), apart from GluR1 which showed a small increase at 20 min post-HFS $(n=11)$ and GluR3 which showed a small decrease $4 \mathrm{~h}$ post-HFS. $e$, Histogram of average ODs showing no increase in GluR1-3 subunit levels in whole cell extracts isolated $20 \mathrm{~min}$ and $4 \mathrm{~h}$ post-HFS ( $n$ values $=4-6$ ). A modest reduction in GluR3 levels was found $4 \mathrm{~h}$ post-HFS. All data in this and all following figures reflect the relative percentage difference in optical density between tetanized and control hemispheres on the same Western blot. Asterisks in all figures signify a significant difference by paired $t$ test, $p \leq$ 0.05 , from the control hemisphere. 
a

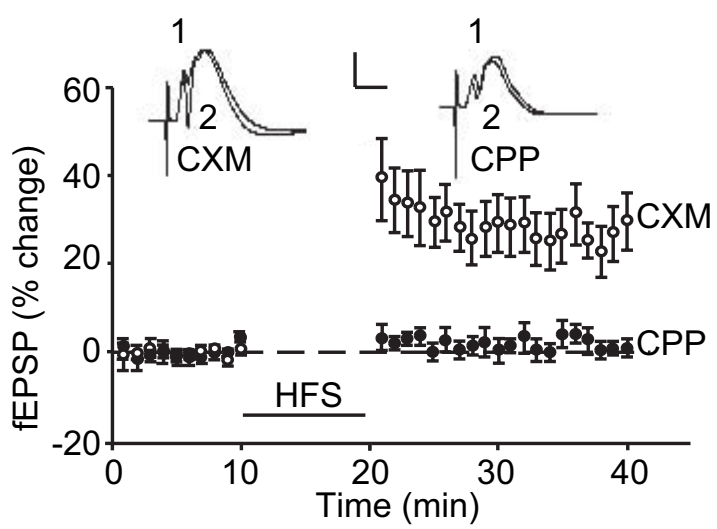

b

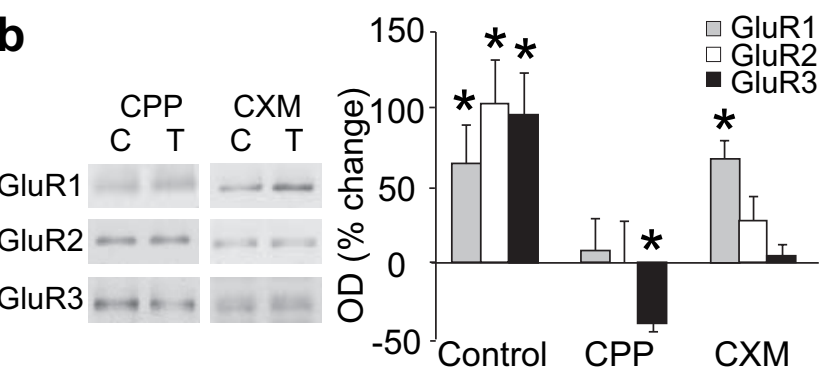

C

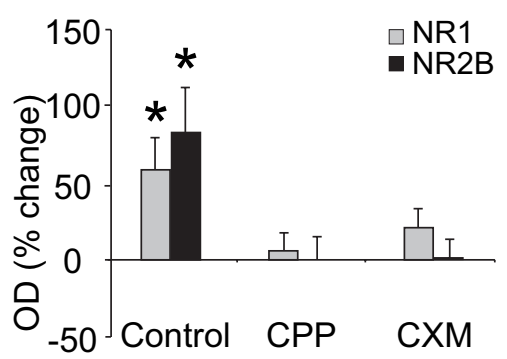

Figure 4. NMDAR- and protein synthesis-dependency of glutamate receptor subunit expression at the cell-surface. $\boldsymbol{a}$, The NMDAR antagonist CPP completely blocked LTP induction $(n=8)$. The protein synthesis inhibitor cycloheximide (CXM) did not affect LTP over the first 20 min of expression ( $n=11$ ). Waveforms are as in Figure 2. $\boldsymbol{b}$, CPP completely blocked GluR1-3 increases at the cell-surface, 20 min post-HFS $(n=4-6)$. Cycloheximide blocked the increases in GluR2 and GluR3 but not GluR1 ( $n=4-8)$. c, Both CPP and cycloheximide blocked NR1 and NR2B increases at the cell-surface of synaptoneurosomes 20 min post-HFS $(n=3-7)$. NR2A levels were not determined. Sample Western blots show glutamate receptor levels in cellsurface extracts isolated 20 min post-HFS from matched control (C) and tetanized (T) hemispheres from a single animal.

gyrus. Both phenomena occurred in the dentate gyrus ipsilateral to perforant path stimulation beginning immediately after the HFS, and were dependent on NMDAR activation, but did not occur after equal density low-frequency stimulation. As we found no evidence of alterations in the levels of other synaptoneurosomal marker proteins such as PSD95 (Williams et al., 2003) or synapsin-1 (D. Guévremont and J. M. Williams, unpublished observations) at $20 \mathrm{~min}$ post-HFS, it appears that early LTP expression in this preparation involves molecular reorganization of existing synapses rather than synaptogenesis. Increased cellsurface AMPAR expression could occur at synapses that are already active (Matsuzaki et al., 2004) or via AMPAR entry into small, electrophysiologically silent synapses (Takumi et al., 1999), although such synapses are unlikely to occur to a significant degree in adult tissue (Durand et al., 1996).

Our finding that GluR1 is the only AMPAR subunit to accumulate at the cell surface during LTP in the presence of cycloheximide, and the only one to increase significantly in the PSD frac-

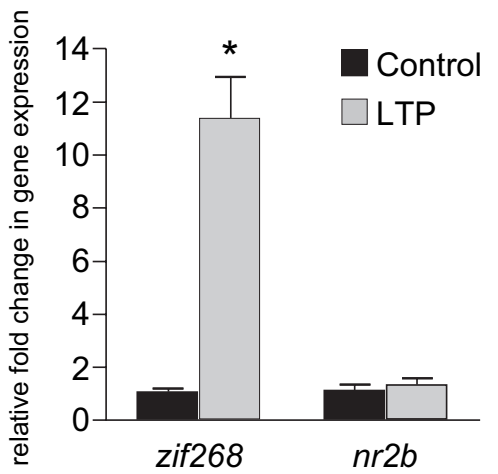

Figure 5. LTP induction at perforant path synapses in awake animals results in an increase in zif/268 but not $n r 2 b$ mRNA levels, as determined by quantitative PCR. A robust 11 -fold increase in zif/268 mRNA levels $(p<0.0001)$ was detected 20 min post-HFS in experimental animals (LTP), whereas no significant change was detected for $n r 2 b$. No difference in zif/268 or $n r 2 b$ mRNA levels was detected between hemispheres of unstimulated, control rats.
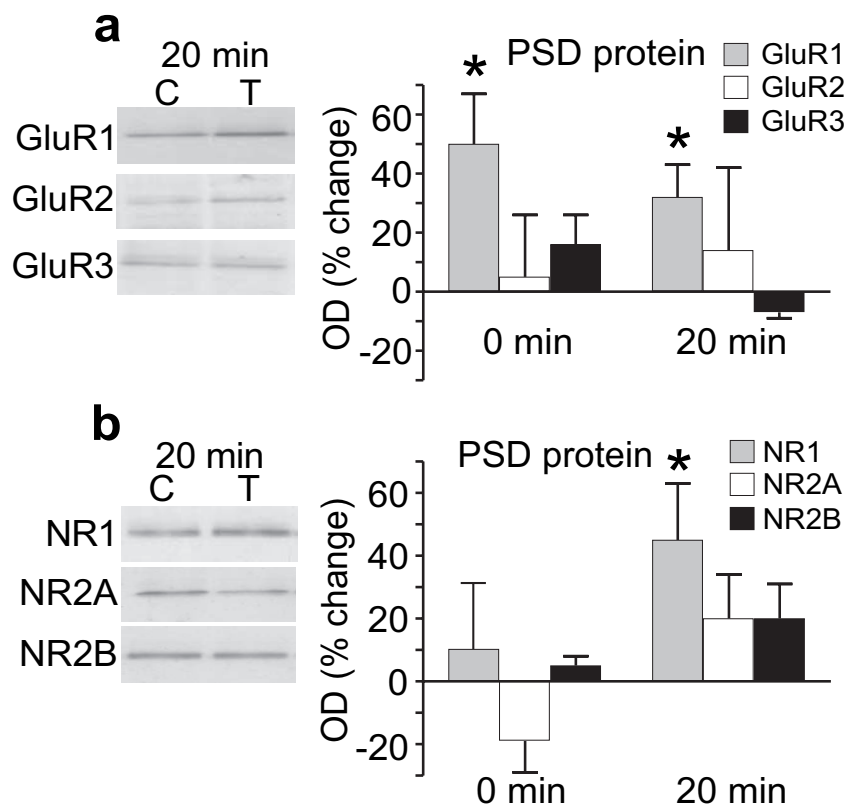

Figure 6. Glutamate receptor subunit expression in a PSD-enriched fraction from synaptoneurosomes isolated after LTP in awake rats. $\boldsymbol{a}, \boldsymbol{b}$, Average results for AMPAR subunits $(\boldsymbol{a})$ and NMDAR subunits $(\boldsymbol{b})$. GluR1 showed a significant increase at 0 min post-HFS $(n=6)$. GluR1 and NR1 showed significant increases 20 min post-HFS $(n=8)$. No increase was observed for GluR2, GluR3, NR2A or NR2B ( $n=4-8$ ) at 0 or $20 \mathrm{~min}$. Sample Western blot, as per Figure 2, shows glutamate subunit expression 20 min post-HFS for control versus tetanized hemispheres.

tion, strongly implicates homomeric GluR1-containing receptors in early LTP expression in vivo. This conclusion is consistent with the fact that the percentage change in the level of GluR1 in the PSD fraction was similar to the measured degree of LTP. It is also consistent with findings in young hippocampal tissue after depolarization or LTP induction in vitro (Hayashi et al., 2000; Malinow and Malenka, 2002; Park et al., 2004), in developing barrel cortex after whisker stimulation (Takahashi et al., 2003), and in the amygdala after fear conditioning (Rumpel et al., 2005). It contrasts, however, with findings in adult CA1 slices where either AMPAR trafficking was not observed (Grosshans et al., 2002) or no evidence could be found for insertion of GluR1 homomeric AMPARs (Adesnik and Nicoll, 2007). These differences may relate to the hippocampal subregions being studied, or 
to some alteration in the way that LTP is expressed in adult tissue when studied in vitro. Also, we cannot rule out in the present study the possibility that some of the accumulated AMPARs contain GluR2, but at a level below detection with our techniques. Thus, future experiments using in vivo electrophysiological tests of the hypothesis are clearly warranted.

Because the levels of GluR2/3 did not change in the PSD fraction, it appears that their trafficking was confined to extrasynaptic sites. This restricted extrasynaptic expression is reminiscent of the GluR1 extrasynaptic accumulation after activation of cAMP signaling pathways and phosphorylation of GluR1 at ser845 (Oh et al., 2006). The rapid accumulation of GluR3 in the apparent absence of GluR2 at 0 min post-HFS was surprising. Although others have reported independent responses of GluR2 and GluR3 to NMDAR activation (Feligioni et al., 2006), if GluR3 homomers are formed they are likely to be poorly trafficked to the PSD (Beretta et al., 2005). In the present case it is not clear whether these results represent an experimental failure to detect actual GluR2 changes at this time point or a trafficking of homomeric GluR3 receptors. Because such receptors are not commonly observed, we favor the former hypothesis, especially because both GluR2 and GluR3 were increased extrasynaptically by 20 min post-HFS. This trafficking may reflect stocking of the extrasynaptic pool for future replacement of synaptic GluR1containing receptors by lateral diffusion, or perhaps their expression on nonsynaptic filopodia (Ostroff et al., 2002).

\section{LTP-related trafficking of NMDARs}

The rapid upregulation of cell-surface AMPAR subunits was soon followed by a trafficking of NMDAR subunits to the cell surface, including into the PSD. The newly inserted NMDARs appeared to be both NR2A- and NR2B-containing. This supports previous findings in CA1 slices (Grosshans et al., 2002) and in visual cortex slices from juvenile rats (Watt et al., 2004). In the present experiments, the upregulation of NMDARs not only tended to re-establish the baseline AMPAR/NMDAR ratio, but also may have fundamentally altered the properties of these synapses by increasing NMDAR calcium transients in response to subsequent stimulation (Thiagarajan et al., 2005).

\section{Differential dependence of glutamate receptor trafficking on de novo protein synthesis}

The observed increase in GluR1 expression in synaptoneurosomes could have arisen from localized synaptodendritic protein synthesis (Smith et al., 2005), as it was not detected in the total cell homogenate. However, it is unlikely that such local synthesis contributed significantly to the LTP-related cell-surface expression given that the increase in synaptoneurosomal GluR1 was relatively small and delayed, and that cycloheximide did not affect GluR1 trafficking to the membrane. Similarly, anisomycin failed to block GluR1 trafficking in cultures (Park et al., 2004). Surprisingly, GluR3 trafficking was completely blocked and GluR2 cell-surface expression was substantially reduced by cycloheximide, suggesting that GluR2/3 trafficking, but not GluR1 homomeric or GluR1/2 heteromeric trafficking, is protein synthesis-dependent. Although the identity of the key synthesized molecule(s) important for GluR2/3 trafficking is not known, our data suggest it is not GluR2 or GluR3 itself and therefore may be a rapidly translated chaperone molecule such as TARP- $\gamma 8$ (Rouach et al., 2005).

In contrast to the GluRs, the previously reported rapid increases in NR2 subunits in synaptoneurosome homogenates (Williams et al., 2003) did appear to entail synaptodendritic pro- tein synthesis of receptor subunits as the synaptoneurosomal increase in NR2B was blocked by cycloheximide and occurred in the absence of any change in $n r 2 b$ mRNA levels. Furthermore, the trafficking of NR1, NR2A and NR2B to the cell surface was also blocked. These data indicate that new protein synthesis is required for LTP-associated NMDAR trafficking, and one mechanism appears to be the need to synthesize NR2A/2B subunits to assemble with pre-existing NR1 molecules before trafficking.

\section{Time dependence of glutamate receptor trafficking}

Given the close relationship between AMPAR trafficking and early-phase LTP, we predicted that an increase in cell-surface AMPARs could also underpin late-phase LTP. However, $4 \mathrm{~h}$ after LTP induction, when robust LTP is still evident, only the cellsurface expression of GluR2 remained elevated. This could still reflect an elevation of AMPARs because GluR2 is found in both GluR1- and GluR3-containing AMPARs and a small increase of both receptor types might mean that GluR2 would be the subunit most easily detected. Nonetheless, the clear decline in cell-surface expression of AMPARs between 20 min and 4 h post-HFS may reflect internalization of superfluous extrasynaptic receptors. Alternatively, a continued increase in GluR1-containing receptors may have been obscured by a reduction in the number of such receptors elsewhere in the tissue. Interestingly, a similar scenario was observed for NMDAR subunit expression at the $4 \mathrm{~h}$ time point, such that a significant residual increase in cell-surface expression was observed for NR2B, but not for NR1 or NR2A. Once again, this could reflect a subunit composition change that in this case emphasizes NR2B-containing receptors.

A final possibility is that the difficulty in documenting a sustained increase in cell-surface expression of AMPARs and NMDARs could have resulted from synaptic scaling (Turrigiano et al., 1998), driven by an LTP-related net increase in excitatory synaptic drive onto the postsynaptic granule cells. The ensuing enhanced postsynaptic activity would initiate via global AMPAR internalization a scaling down of both potentiated and nonpotentiated excitatory synapses on the granule cells, bringing the net synaptic weight back toward the baseline value. Although potentiated synapses would still be stronger than nonpotentiated ones in the tetanized hemisphere, the difference in both synaptic weights and AMPAR receptor distributions between the tetanized and control hemispheres would disappear (Shepherd et al., 2006; Verde et al., 2006). Scaling could also account for the parallel change in NMDAR detectability at the cell surface. This loss of resolution would not be observed in the electrophysiological recordings, because with this technique one is able to selectively sample the potentiated synapses.

\section{References}

Abraham WC, Mason SE (1988) Effects of the NMDA receptor antagonists CPP and MK801 on hippocampal field potentials and long-term potentiation in urethane anaesthetized rats. Brain Res 462:40-46.

Adesnik H, Nicoll RA (2007) Conservation of glutamate receptor 2-containing AMPA receptors during long-term potentiation. J Neurosci 27:4598-4602.

Barria A, Malinow R (2002) Subunit-specific NMDA receptor trafficking to synapses. Neuron 35:345-353.

Beretta F, Sala C, Saglietti L, Hirling H, Sheng M, Passafaro M (2005) NSF interaction is important for direct insertion of GluR2 at synaptic sites. Mol Cell Neurosci 28:650-660.

Chen L, Chetkovich DM, Petralia RS, Sweeney NT, Kawasaki Y, Wenthold RJ, Bredt DS, Nicoll RA (2000) Stargazin regulates synaptic targeting of AMPA receptors by two distinct mechanisms. Nature 408:936-943.

Chen N, Luo T, Raymond LA (1999) Subtype-dependence of NMDA receptor channel open probability. J Neurosci 19:6844-6854. 
Durand GM, Kovalchuk Y, Konnerth A (1996) Long-term potentiation and functional synapse induction in developing hippocampus. Nature 381:71-75.

Ehlers MD (2000) Reinsertion or degradation of AMPA receptors determined by activity-dependent endocytic sorting. Neuron 28:511-525.

Feligioni M, Holman D, Haglerod C, Davanger S, Henley JM (2006) Ultrastructural localisation and differential agonist-induced regulation of AMPA and kainate receptors present at the presynaptic active zone and postsynaptic density. J Neurochem 99:549-560.

Grosshans DR, Clayton DA, Coultrap SJ, Browning MD (2002) LTP leads to rapid surface expression of NMDA, but not AMPA receptors in adult rat CA1. Nat Neurosci 5:27-31.

Hayashi Y, Shi SH, Esteban JA, Piccini A, Poncer JC, Malinow R (2000) Driving AMPA receptors into synapses by LTP and CaMKII: requirement for GluR1 and PDZ domain interactions. Science 287:2262-2267.

Heynen AJ, Quinlan EM, Bae DC, Bear MF (2000) Bidirectional, activitydependent regulation of glutamate receptors in the adult hippocampus in vivo. Neuron 28:527-536.

Hollingsworth EB, McNeal ET, Burton JL, Williams RJ, Daly JW, Creveling CR (1985) Biochemical characterization of a filtered synaptoneurosome preparation from guinea pig cerebral cortex: cyclic adenosine $3^{\prime}: 5^{\prime}$ monophosphate-generating systems, receptors, and enzymes. J Neurosci 5:2240-2253.

Holman D, Henley JM (2007) A novel method for monitoring the cell surface expression of heteromeric protein complexes in dispersed neurons and acute hippocampal slices. J Neurosci Meth 160:302-308.

Huh KH, Wenthold RJ (1999) Turnover analysis of glutamate receptors identifies a rapidly degraded pool of the N-methyl-D-aspartate receptor subunit, NR1, in cultured cerebellar granule cells. J Biol Chem 274:151-157.

Lee HK, Barbarosie M, Kameyama K, Bear MF, Huganir RL (2000) Regulation of distinct AMPA receptor phosphorylation sites during bidirectional synaptic plasticity. Nature 405:955-959.

Liao L, Pilotte J, Xu T, Wong CC, Edelman GM, Vanderklish P, Yates III JR (2007) BDNF induces widespread changes in synaptic protein content and up-regulates components of the translation machinery: an analysis using high-throughput proteomics. J Proteome Res 6:1059-1071.

Lissin DV, Gomperts SN, Carroll RC, Christine CW, Kalman D, Kitamura M, Hardy S, Nicoll RA, Malenka RC, von Zastrow M (1998) Activity differentially regulates the surface expression of synaptic AMPA and NMDA glutamate receptors. Proc Natl Acad Sci USA 95:7097-7102.

McCormack SG, Stornetta RL, Zhu JJ (2006) Synaptic AMPA receptor exchange maintains bidirectional plasticity. Neuron 50:75-88.

Malinow R, Malenka RC (2002) AMPA receptor trafficking plasticity and synaptic plasticity. Annu Rev Neurosci 25:103-126.

Matsuzaki M, Honkura N, Ellis-Davies GC, Kasai H (2004) Structural basis of long-term potentiation in single dendritic spines. Nature 429:761-766.

Mockett B, Guévremont D, Williams JM, Abraham WC (2007) Dopamine D1/D5 receptor activation reverses NMDA receptor-dependent longterm depression in rat hippocampus. J Neurosci 27: 2918-2926.

Moga DE, Shapiro ML, Morrison JH (2006) Bidirectional redistribution of AMPA but not NMDA receptors after perforant path simulation in the adult rat hippocampus in vivo. Hippocampus 16:990-1003.

Montgomery JM, Selcher JC, Hanson JE, Madison DV (2005) Dynamindependent NMDAR endocytosis during LTD and its dependence on synaptic state. BMC Neurosci 6:48.

Nayak A, Zastrow DJ, Lickteig R, Zahniser NR, Browning MD (1998) Maintenance of late-phase LTP is accompanied by PKA-dependent increase in AMPA receptor synthesis. Nature 394:680-683.

Nong Y, Huang YQ, Ju W, Kalia LV, Ahmadian G, Wang YT, Salter MW (2003) Glycine binding primes NMDA receptor internalization. Nature 422:587-596.

Oh MC, Derkach VA, Guire ES, Soderling TR (2006) Extrasynaptic membrane trafficking regulated by GluR1 serine 845 phosphorylation primes AMPA receptors for long-term potentiation. J Biol Chem 281:752-758.

Ostroff LE, Fiala JC, Allwardt B, Harris KM (2002) Polyribosomes redistribute from dendritic shafts into spines with enlarged synapses during LTP in developing rat hippocampal slices. Neuron 35:535-545.

Park M, Penick EC, Edwards JG, Kauer JA, Ehlers MD (2004) Recycling endosomes supply AMPA receptors for LTP. Science 305:1972-1975.

Passafaro M, Piëch V, Sheng M (2001) Subunit-specific temporal and spa- tial patterns of AMPA receptor exocytosis in hippocampal neurons. Nat Neurosci 4:917-926.

Perez-Otano I, Ehlers MD (2005) Homeostatic plasticity and NMDA receptor trafficking. Trends Neurosci 28:229-238.

Plant K, Pelkey KA, Bortolotto ZA, Morita D, Terashima A, McBain CJ, Collingridge GL, Isaac JT (2006) Transient incorporation of native GluR2-lacking AMPA receptors during hippocampal long-term potentiation. Nat Neurosci 9:602-604.

Rouach N, Byrd K, Petralia RS, Elias GM, Adesnik H, Tomita S, Karimzadegan S, Kealey C, Bredt DS, Nicoll RA (2005) TARP gamma-8 controls hippocampal AMPA receptor number, distribution and synaptic plasticity. Nat Neurosci 8:1525-1533.

Rumpel S, LeDoux J, Zador A, Malinow R (2005) Postsynaptic receptor trafficking underlying a form of associative learning. Science 308:83-88.

Salvatore MF, Apparsundaram S, Gerhardt GA (2003) Decreased plasma membrane expression of striatal dopamine transporter in aging. Neurobiol Aging 24:1147-1154.

Scheurer SB, Rybak JN, Roesli C, Brunisholz RA, Potthast F, Schlapbach R, Neri D, Elia G (2005) Identification and relative quantification of membrane proteins by surface biotinylation and two-dimensional peptide mapping. Proteomics 5:2718-2728.

Shepherd JD, Rumbaugh G, Wu J, Chowdhury S, Plath N, Kuhl D, Huganir RL, Worley PF (2006) Arc/Arg3.1 mediates homeostatic synaptic scaling of AMPA receptors. Neuron 52:475-484.

Shi SH, Hayashi Y, Petralia RS, Zaman SH, Wenthold RJ, Svoboda K, Malinow R (1999) Rapid spine delivery and redistribution of AMPA receptors after synaptic NMDA receptor activation. Science 284:1811-1816.

Skeberdis VA, Lan J, Zheng X, Zukin RS, Bennett MV (2001) Insulin promotes rapid delivery of $N$-methyl-D-aspartate receptors to the cell surface by exocytosis. Proc Natl Acad Sci USA 98:3561-3566.

Smith WB, Starck SR, Roberts RW, Schuman EM (2005) Dopaminergic stimulation of local protein synthesis enhances surface expression of GluR1 and synaptic transmission in hippocampal neurons. Neuron 45:765-779.

Strack S, Choi S, Lovinger DM, Colbran RJ (1997) Translocation of autophosphorylated calcium/calmodulin-dependent protein kinase II to the postsynaptic density. J Biol Chem 272:13467-13470.

Takahashi T, Svoboda K, Malinow R (2003) Experience strengthening transmission by driving AMPA receptors into synapses. Science 299:1585-1588.

Takumi Y, Ramírez-León V, Laake P, Rinvik E, Ottersen OP (1999) Different modes of expression of AMPA and NMDA receptors in hippocampal synapses. Nat Neurosci 2:618-624.

Taubenblatt P, Dedieu JC, Gulik-Krzywicki T, Morel N (1999) VAMP (synaptobrevin) is present in the plasma membrane of nerve terminals. J Cell Sci 112:3559-3567.

Thiagarajan TC, Lindskog M, Tsien RW (2005) Adaptation to synaptic inactivity in hippocampal neurons. Neuron 47:725-737.

Turrigiano GG, Leslie KR, Desai NS, Rutherford LC, Nelson SB (1998) Activity-dependent scaling of quantal amplitude in neocortical neurons. Nature 391:892-896.

Verde EMR, Lee-Osbourne J, Worley PF, Malinow R, Cline HT (2006) Increased expression of the immediate-early gene Arc/Arg3.1 reduces AMPA receptor-mediated synaptic transmission. Neuron 52:461-474.

Watt AJ, Sjöström PJ, Hausser M, Nelson SB, Turrigiano GG (2004) A proportional but slower NMDA potentiation follows AMPA potentiation in LTP. Nat Neurosci 7:518-524.

Wenthold RJ, Prybylowski K, Standley S, Sans N, Petralia RS (2003) Trafficking of NMDA receptors. Annu Rev Pharmacol Toxicol 43:335-358.

Williams JW, Mason-Parker SE, Abraham WC, Tate WP (1998) Biphasic changes in the levels of $N$-methyl-D-aspartate receptor-2 subunits correlate with the induction and persistence of long-term potentiation. Mol Brain Res 60:21-27.

Williams JM, Guévremont D, Kennard JT, Mason-Parker SE, Tate WP, Abraham WC (2003) Long-term regulation of $N$-methyl-D-aspartate receptor subunits and associated proteins following hippocampal synaptic plasticity. Neuroscience 118:1003-1013.

Zhong WX, Dong ZF, Tian M, Cao J, Xu L, Luo JH (2006) N-methyl-Daspartate receptor-dependent long-term potentiation in CA1 region affects synaptic expression of glutamate receptor subunits and associated proteins in the whole hippocampus. Neuroscience 141:1399-1413. 